of Bloody Saturday, that secured the Citizens' victory over the strikers. The material thrust of capital's counterattack is thus underemphasized. Furthermore, far from teaching us about the strike as the response of that nebulous force, "a liberal order," we see how the capitalists of Winnipeg discarded liberalism, jettisoning all notions of British justice, the separation of the class interest and the state, and individual liberty in their usurpation of the state to crush the strike. In the end, the liberal ideology of the Citizens boils down to Marx's dictum that "the ruling ideas are the ideas of the ruling classes;" they are evidence of power, not power's source.

This is the missed opportunity of When The State Trembled: despite the authors' premises, they account not for the triumph of ideology or the response of that nebulous creature, a liberal order, but for the ability of capital to usurp the legitimacy of the state in order to defeat a working-class challenge. Yet the authors persistently overlook the dimensions of class conflict or capitalism in their analysis, preferring instead to argue that what is revealed by the General Strike's repression is primarily about the state and civil society, languages of rule, and discourses of citizenship. Of course, it is that perceived separation between the "economic" and the "political" that is a key strategy of capitalist domination, and one used effectively by the Citizens' themselves. Ideology and state formation are important, but it is crucial to couple our understanding of the uses of ideology with an appreciation of the material force of class conflict, dimensions often understated by recent constructions of Canada as a liberal order.

Nevertheless, Kramer and Mitchell have written a book of enormous value that will no doubt receive the highest honour available to a work of history: to be drawn on and debated for years to come.

Jeremy Milloy

Simon Fraser University

\title{
Peter Campbell, Rose Henderson: $A$ Woman for the People (Montreal: McGill-Queens University Press, 2010).
}

Historians of the Canadian Left are well acquainted with communist leaders like Becky Buhay, with early architects of the Cooperative Commonwealth Federation (CCF), like Agnes Macphail, and with female parliamentarians like New Democrat Grace MacInnis. Yet, had we had lived through the Great Depression, particularly in Ontario, the name we might have first associated with the cause of socialism was that of Rose Henderson. Henderson led a remarkable life, much of it devoted to politics, writing, and organizing for feminist, socialist, labour, and peace causes, which to her were never distinct, but all intimately linked. Thanks to Peter Campbell, Henderson has been rescued from the 'conde- 
scension of posterity' and placed at the centre rather than the periphery of the history of the Canadian left. Campbell's deeply-researched and compelling biography not only provides a complex picture of Henderson's political ideas, but it also offers new perspectives on the history of feminism, the left, and peace activism in Canada.

If Rose Henderson had not died rather young at the height of her political prominence in 1937, she might have assumed a more central place in the history of the left; yet, as Campbell makes clear, her portrayal in the annals of Canadian socialism has also been compromised by a tendency to downplay the importance of women's socialist organizing, and by a misrepresentation of her role in the early CCF by some historians with a particular social democratic agenda. Henderson first became politically visible in pre-World War I Montreal. Though we know little of her family background, she was Irish by birth, was widowed quite young, with one daughter, and though middle class, may have had some training in 'social welfare' work. She was publicly active as a reformer, dedicated to the protection of youth, and was appointed one of the first female probation officers in the newly-created Montreal Juvenile Court in 1912. According to Campbell, Henderson, unlike some other middle-class reformers of the time, stressed the environmental causes of poverty, degeneracy, and delinquency amongst the poor; as such, their condition was alterable, not inevitable. Nonetheless, it is interesting to read Campbell's biography in tandem with Tamara Myer's discussion of Henderson in her Caught:_Montreal's Modern Girls and the Law, 1869-1945; in this book, Henderson appears a little less sympathetic, and often quite judgemental, about mothers' individual failings and morality. There is no doubt, however, that Henderson's professional work with working-class and poor families, combined with her political leanings, led to her increasingly radical critique of the status quo by the end of the First World War, so much so that she was investigated as a subversive by the state, and dismissed from her job. Her rousing speech to the 1919 Mathers Commission on industrial unrest, which indicted capitalism as the cause of working class misery and called for revolutionary change, was just one example of her compelling way with words, and her ability to translate her political passion into powerful oratory.

Campbell traces Henderson's political work for the next eighteen years; this is not an easy task, given her multiple political allegiances and causes, and, perhaps most important, the lack of any cache of her personal papers.

Campbell's success in reconstructing Henderson's political work and ideas is thus quite stunning, given the detective work needed, and his careful and comprehensive research is one of the major strengths of the book. By combing archival collections in Canada and abroad, he is able to locate some of her letters, and he makes thorough use of CCF and labour archives, as well as newspaper, labour papers, and printed material, as much as one could possibly locate. By combin- 
ing, comparing, and juxtaposing multiple sources, he is able to provide a fulsome description of her work, and a convincing analysis of her ideas, some of which reflected continuity over time, while others shifted, as the political situation and opportunities altered. The lack of any Henderson papers does leave an unavoidable gap in his discussion of her personal life and relationships, but Campbell compensates by drawing as detailed a portrait of her political life as possible, using her public statements and actions to surmise something of her personality.

From 1920 to 1937, Henderson did not go from one cause to another in a linear fashion, as she was often campaigning on more than one front. However, she did concentrate her political work at certain time periods. In the 1920s, her peace work was particularly prominent, and her membership in the early twenties in the Women's Peace Union, an "absolutist pacifist" (143) organization, put her at the 'radical' end of feminist peace work. Henderson was also an ardent advocate for the labour movement. She became one of the most popular speakers on the labour circuit during the twenties; her dismissal had only increased her status as a "working class hero" (74) for many trade unionists. At the same time, Henderson's middle-class economic security allowed her to travel abroad as a political tourist, and like a number of radicals of this generation, she visited the new Soviet Union, then relayed her impressions to audiences on her return. By the 1930s, after her relocation to Toronto, she was deeply involved in the Ontario Labour Party, and she played a role in the founding of the early CCF. It is in this context that Campbell argues she has been entirely misrepresented by social democratic historians who are dismissive of labour and socialist activists of the time who had criticisms of the way the party was being constructed. While Henderson was clearly concerned that the labour and workingclass nature of the party not be sacrificed on the alter of middle-class CCF clubs, she was never the destructive and "doctrinaire" (212) socialist she was later portrayed as by Terry Crowley and Gerald Caplan. It is true that Henderson never abandoned her desire to work collaboratively with other leftists, including communists. However, she became increasingly committed to the CCF, and ran successfully as a CCF candidate for the Toronto School Board, thus continuing with her life-long commitment to advocate for children and youth.

Unlike the right-leaning defenders of social democracy like Crowley and Caplan, socialist feminist historians of the 1980s and 1990s had a very different interest in recovering the history of Rose Henderson. What they saw was a woman who was committed to socialism and feminism, to labour and women, and to a critique of imperialism and capitalism; she embodied a political praxis that sought to understand and challenge the complex, multiple structures of oppression and exploitation that shaped the lives of women and the working class. This is clearly what interests Campbell, and he is skilled at showing how her analysis of gender and class power was constructed and intertwined, how 
Henderson "did not focus on any one of the major hierarchies of power in capitalist society, but rather on them all" (111). Henderson's life thus helps to substantiate the long durée of socialist -feminist organizing in Canadian history, and disputes the notion that a first wave of feminism was followed by a trough of inactivity. Henderson's commitment to multiple issues also resulted in life-long connections to middle-class and working-class women's groups, to women and men, to women across religious lines, and to a variety of leftists. In one sense, the amazing 'reach' of her political impact makes Campbell's reconstructive work easier, as there are many threads to her life, though the biographical feat is in tying them together, and Campbell has done this well.

Campbell is clearly sympathetic to his subject, understandably so. $\mathrm{He}$ does attempt to step back on occasion, pointing to inconsistencies or contradictions in her politics, and there are some puzzles about Henderson's own selfconstruction which we need to address. Why, in the 1930s, did she suddenly list a $\mathrm{PhD}$ after her name in her political self-descriptions? This doctoral designation was derided by communist Stanley Ryerson, who would have known such degrees were hard to come by, yet Campbell does not really explain this newfound doctorate - which, after all, if non-existent, would be looked on pretty dubiously today.

Campbell also uses Henderson as a window into feminist, pacifist, and socialist politics of the time, and a means of re-interpreting the existing historiography of women and the left. This has both positive and problematic results. On the one hand, his careful use of sources helps him, for example, re-write the history of the making of the early CCF in Ontario, and untangle, with thoughtful precision, the various feminist peace groups that emerged after World War I. On the other hand, his claims for Henderson sometimes outweigh the evidence, or set up straw historiographical arguments. For example, the claim that Henderson's discussion of youth leisure, smoking and drinking provides "a more reliable guide to the lives of ordinary young Canadians" than work by Cynthia Commachio, seems off the mark (200). Similarly, Campbell discusses

Henderson's ability to work across party lines with communists, but then goes on to claim that other historians (who are not cited) have "mistakenly" assumed communists simply ignored non-communists during the communist party's ultra left turn, and that communist "rhetoric was not reality....the point is that there was no dramatic watershed between the Third Period from the Second before it or the Popular Front that followed it" (171). Again, it seems exaggerated to claim that the Third Period was simply "rhetoric" (after all political rhetoric has meaning and power) and to downplay its "realities." After all, we know from other research (such as Ruth Frager's) that communist dual unions of the Third Period did have very real - and sometimes negative - political effects. Henderson, in other words, is a useful window into socialist and feminist politics, but her exam- 
ple can only be taken so far.

Campbell's claim for Henderson's significance in his introduction seems almost unnecessary, and at times also off the historiographical mark. He sees the book challenging the "claim made by Canadian historians that being a maternal feminist...involved the depoliticization of women," yet many feminist historians recognize the deeply political nature of maternal feminism - even if they are critical of it. Similarly, to argue that Bettina Bradbury "shifted" feminist scholarship away from Joan Sangster's focus on "elite women" (4) to a new emphasis on "ordinary women," suggests political and scholarly differences between two socialist-feminist historians which did not really exist. Campbell's biography of Henderson is so important, so very well done, that it needs little historigraphical justification. Henderson was, on one hand, a unique, extraordinary, politically talented woman whose life is interesting in its own right. She was also a political actor among others, part of wider efforts to build resistance to capitalism, gender oppression, and war. We are in great debt to Campbell for reconstructing an extraordinary life neglected for too long.

Joan Sangster

Trent University

\section{Marc Stein, Sexual Injustice: Supreme Court Decisions from Griswold to Roe (Chapel Hill, University of North Carolina Press, 2010).}

Clive Boutilier, a Canadian immigrant to the United States who had had homosexual experiences, was refused naturalization in a 1967 Supreme Court decision, Boutilier v. the Immigration and Naturalization Service on the basis of a 1952 immigration law permitting exclusion of those "afflicted with psychopathic personality" (61). He was deported to Canada in 1968 after being severely injured and permanently disabled when a car struck him on a New York street in what may have been a suicide attempt. Moved by this tragic and little known story, Marc Stein has investigated the contradiction between Boutilier's treatment and the powerful narrative of sexual liberalization that has dominated accounts of five significant U.S. Supreme Court decisions between 1965 and 1973, especially Griswold v. Connecticut (birth control), Memoirs of a Woman of Pleasure [Fanny Hill] $v$.

Massachusetts (obscenity), Loving v. Virginia (interracial marriage), Eisenstadt v. Baird (access to birth control for the unmarried), and Roe v. Wade (abortion). He argues that the narrative of liberalization ignores how the Court's decisions upheld "a legal regime of heteronormative supremacy" (21) and liberalized only reproductive and marital, not broadly sexual, rights. Hence, the Lawrence v. Texas decision of 2003 that invalidated sodomy laws was not a culmination but a reversal of earlier views. 